\title{
"The Future in the Land belongs to us": Conflicting Perceptions on the Land in Jeremiah 32:1-44 (LXX 39:1-44).
}

\author{
MaRiUS TERBLANCHE \\ (University OF THE Free State, South Africa)
}

\begin{abstract}
This article examines Jeremiah 32, a chapter closely linked to the purchase of a field in Anathoth by the prophet Jeremiah at a time when the fall of Jerusalem in 587 B.C.E. was imminent. Jeremiah 32 is a multilayered text presenting evidence of the adaptation of Jeremiah's signact by various groups. While it is likely that the oldest core, verses $6 b$ 15 , presents the perspective of the people remaining in Judah after 587 B.C.E., in its final form the chapter promotes the interests of the Babylonian exiles. Although the uncovering of conflicting perceptions with regard to the land demonstrates that the use of Jeremiah 32 in present-day reflections on the land question is risky, the chapter highlights the importance of land issues. It furthermore demonstrates that biblical texts, applied in contemporary land issues, should be subjected to exhaustive redactional analyses. The different redactional stages of the texts may reveal conflicting ideologies.
\end{abstract}

KEYWORDS: Empty Land, Exiles, Land, Land ideology, Remainees

\section{A INTRODUCTION}

The land is a particularly important theme in the book of Jeremiah. ${ }^{1}$ This is noticeable from the close connection between the land and people. ${ }^{2}$ The land is repeatedly described as the נחלה, "possession", of YHWH (cf. Jer. 2: 7; 3:19; 16:18; 50:11). Remarkably Israel is also called the נחלה of YHWH (cf. 10:16; 51:19). Israel knew that YHWH had given them the land. ${ }^{3}$ Exile, which is repeatedly foretold, therefore meant more than merely the loss of the land. Every

* Submitted: 22/08/2019; peer-reviewed: 04/03/2020; accepted: 06/03/2020. Marius Terblanche,"“The future in the Land belongs to us': Conflicting perceptions on the Land in Jeremiah 32:1-44 (LXX 39:1-44)." Old Testament Essays 33 no. 1 (2020): 107 - 124. DOI: https://doi.org/10.17159/2312-3621/2020/v33n1a7.

1 Brueggemann views the land as a central, if not the central theme of biblical faith. Cf. Walter Brueggemann, The Land (London: SPCK, 1978), 3.

2 Cf. Walter Zimmerli, "Das 'Land' bei den vorexilischen und frühexilischen Schriftprophet," in Das Land Israel in biblischer Zeit: Jerusalem Symposium 1981 (ed. Georg Strecker; Göttingen: Vandenhoeck \& Ruprecht, 1983), 38.

3 Cf. Christopher J.H. Wright, Old Testament Ethics for the People of God (Downers Grove: IVP Academic, 2004), 88. 
promise seemed void. ${ }^{4}$ Although announcements of the loss of the land predominate, some texts in the book of Jeremiah express a hope for a future life in Judah. In this regard Jeremiah 32 is of special significance. It reports that at point at which all seemed doomed, YHWH instructed the prophet Jeremiah to purchase a field in Anathoth from his nephew Hanamel (32:6-7). YHWH furthermore promises that houses, fields and vineyards would again be bought in the land (32:15). This sign-act signified that there was hope for life in the land in spite of Jerusalem's precarious situation. ${ }^{5}$

Habel has suggested that the narrative in Jeremiah 32 is consistent with the ideology of the book, namely those of the elite Israelites in the Babylonian exile. ${ }^{6}$ In 32:44 the promise that houses, fields and vineyards would again be bought, is explicitly extended to the areas around Jerusalem, the towns in Judah, the hill country and the Negev. The hope associated with Jeremiah's purchase of the field in Anathoth prior to the fall of Jerusalem in 587 B.C.E., now obviously relates to the return and re-occupation of the land after the exile. ${ }^{7}$

Habel identifies six distinct land ideologies in the Old Testament. He believes that these land ideologies are generally written from the perspective of the landowners or would-be landowners. ${ }^{8}$ Although the book of Jeremiah seems to have a purposeful theological design, ${ }^{9}$ there is clear evidence of the hands of opposing groups. ${ }^{10}$ It has been suggested that Jeremiah 32 is a multi-layered

4 Cf. Brueggemann, The Land, 9.

5 Robert P. Carroll, Jeremiah: A Commentary (London: SCM Press, 1986), 621-622, believes that the action was not really performed by Jeremiah, but is only a literary, paradigmatic account.

6 Cf. Norman C. Habel, The land is mine: Six Biblical Land Ideologies (Minneapolis: Fortress, 1995), 89.

7 Christopher R. Seitz, Theology in Conflict: Reactions to the Exile in the Book of Jeremiah (Berlin: De Gruyter, 1989), 245.

8 The ideologies were promoted by particular social groups with vested interests in promoting a given ideology to gain, regain or maintain land. Cf. Habel, The Land, 134148. Habel's attempt to identify the persons or parties alleged to have produces the various land ideologies has, however, been criticized. Cf. Wright, Old Testament Ethics, 85.

9 Cf. Louis Stulman, Order amid Chaos: Jeremiah as Symbolic Tapestry (Sheffield: Sheffield Academic Press, 1998), 17.

10 Sharp identifies a pro-golah group that opposed a Judah-based group. Sharp's argument that the pro-golah group is to be identified by a call to submission to Nebuchadnezzar's authority is however questionable. To be pro-golah does not necessarily imply that one would be pro-Babylonian. Cf. Carolyn J. Sharp, Prophecy and Ideology in Jeremiah: Struggles for Authority in Deutero-Jeremainic Prose (London: T \& T Clark, 2003), 158-159. 
chapter that contains a plurality of both dominant and subordinate voices. ${ }^{11} \mathrm{It}$ would be fruitful to see whether Jeremiah 32 presents more than one view on the land.

In 2017 West $^{12}$ by way of a reappraisal reactivated the ideologicalredactional work of Itumeleng Mosala, a representative of South African Black Theology. Mosala argues that the texts of the Bible are sites of struggle. ${ }^{13}$ His primary focus is on the sites of struggle that produced and are evident within the various redactional editions of the biblical texts. Mosala's emphasis is not so much the redactional process as the identification of the ideological voices within each redaction. ${ }^{14}$ It seems plausible that the different layers of redaction of Jeremiah 32 would reveal conflicting voices with regard to the land.

There is widespread agreement that Jeremiah $32: 6 \mathrm{~b}-15^{15}$ represents the oldest core of chapter $32 .{ }^{16}$ Mastnjak $^{17}$ emulates Thiel ${ }^{18}$ by attributing verses 16 44 to the so-called Deuteronomistic redaction of the book of Jeremiah. Albertz, who differentiates between three Deuteronomistic editions of the book of Jeremiah, attributes verses 16-44 to the third edition. He believes that the object of that edition was to instruct the people not to squander once more the great opportunity announced by the victories of Darius over the Babylonian rebels (522/521 B.C.E.). ${ }^{19}$ The four messenger formulae in verses 26, 28, 36 and 42 are

11 Stegeman, Janneke, “'Reading Jeremiah makes me angry!' The Role of Jeremiah 32[39]:36-41 in Transformation within the 'Jeremianic' Tradition," in Tradition and Innovation in Biblical Interpretation: Studies presented to Professor Eep Talstra on the Occasion of his Sixty-Fifth Birthday (ed. Wido Th.van Peursen and Janet W. van Dyk; Leiden: Brill, 2011), 64.

12 Cf. Gerald West, "Redaction criticism as a Resource for the Bible as 'A Site of Struggle'," OTE 30 (2017) 527.

13 Itumeleng J. Mosala, Biblical Hermeneutics and Black Theology in South Africa (Grand Rapids: Eerdmans, 1990), 185.

14 Cf. West, "Redaction criticism", 533.

15 Cf. Christof Hardmeier, "Jeremia 32,2-15* als Eröffnung der Erzählung von der Gefangeneschaft und Befreiung Jeremias in Jer 34,7; 37,3-40,6*," in Jeremia und die "deuteronomistische Bewegung" (ed. Walter Gross; Weinheim: Beltz Athänaum, 1995), 198. Jer. 32:1-6a can be attributed to a post-Deuteronomistic author. Cf. Windfried Thiel, Die deuteronomistiche Redaktion von Jeremia 26 bis 45: Mit einer Gesamtbeurteilung der deuteronomistichen Redaktion des Buches Jeremia (Neukirchen-Vluyn: Neukirchener Verlag, 1981),30.

16 Cf. Thiel, Die deuteronomistiche Redaktion, 31; Seitz, Theology in Conflict, 243.

17 Cf. Nathan Mastnjak, Deuteronomy and the Emergence of Textual Authority in Jeremiah (Tübingen: Mohr Siebeck, 2016), 158.

18 Cf.Thiel, Die deuteronomistiche Redaktion, 37.

19 Cf. Rainer Albertz, Israel in Exile: The History and Literature of the Six Century B.C.E. (Trans. David Green; Atlanta: Society of Biblical Literature, 2003), 342-343. 
however perhaps signs of ongoing supplementation and expansion. ${ }^{20}$ The uniformity in style and vocabulary in 32:16-44 does not establish that it is the work of a single redactor. ${ }^{21}$

The problem of land possession is timeless and without national boundaries. ${ }^{22}$ Postcolonial theory has revealed that colonizers often identified themselves with the conquering Israelites of the Bible. ${ }^{23}$ Although the existence of conflicting views with regard to the land makes the use of Biblical texts in present-day reflections on the land question risky, a text such as Jeremiah 32 with its emphasis on the land should necessarily be taken into consideration in this debate.

This article will begin with an examination of the different redactional layers in the chapter. This will determine whether these layers reflect different perceptions with regard to the land. A related issue, namely the notion of the empty land, will then be considered. Finally, the implications for the identification of different voices with regard to the land for the use of this chapter in present-day reflections on the land question will be considered.

\section{B DIVERSE PERSPECTIVES ON THE LAND}

\section{The Perspective of the Remainees}

As Pohlmann ${ }^{24}$ and Seitz ${ }^{25}$ have observed, Jeremiah 32:6b-15 fit remarkably well into the context suggested by chapters 37 and 38, namely between the present end of chapter 37 and the beginning of chapter 38 . The activity of $32: 6 b-15$, the purchase of the field in Anathoth, provides a coherent explanation for the fierce opposition of the princes to Jeremiah and their charge that he was weakening the people left to defend Jerusalem.

20 Cf. Walter Brueggemann, "A 'characteristic' Reflection on what comes next (Jeremiah 32.16-44), " in Prophets and Paradigms: Essays in Honour of Gene M. Tucker (ed. Stephen B. Reid; Sheffield: Sheffield Academic Press, 1996), 250.

21 Cf. William McKane, A Critical and Exegetical Commentary on Jeremiah: Volume II (London: Bloomsbury, 2014), 848-849.

22 Cf. Robert Wafawanaka, "'The Land is Mine!' Biblical and Postcolonial Reflections on Land with particular Reference to the Land Issue in Zimbabwe," in Postcolonial Perspectives in African Biblical Interpretations (ed. Musa W. Dube, Andrew M. Mbuvi and Dora Mbuwayesango; Atlanta: Society of Biblical Literature, 2012), 232.

23 Wafawanaka, "'The Land is Mine!"”, 223.

24 Karl-Friedrich Pohlmann, Studien zum Jeremiabuch: Ein Beitrag zur Frage nach der Entstehung des Jeremiabuches (Göttingen: Vandenhoeck \& Ruprecht, 1978) 4647.

25 Cf. Seitz, Theology in Conflict, 243-244. 
Does the text of Jeremiah 32:6b-15 allow for its use by the remainees? Could this narrative at one time have advanced the perspective of the not-exiled Judeans that counted on a continued life in the land. Verse 14 discloses that Baruch was instructed to put the sealed and the unsealed copy of the deed of purchase of the field in a clay jar, so that they would last a long time. It does not necessarily imply that a long time would elapse before houses, fields and vineyards would again be bought in the land (verse 15). ${ }^{26}$ The preservation of the purchase deed was presumably meant to survive the risks posed by a siege culminating in conflagration. ${ }^{27}$

Jeremiah 32:15 may be echoed by 39:10, which proclaims that Nebuzaradan gave the poor people "vineyards and fields" (כרמים ויגבים).28 Römer suggests that a hope for a continued existence in the land is visible in the non-deuteronomic sections of Jeremiah 37-44. According to him Jeremiah's choice to remain with the not-exiled population in Judah implies continuity of the relation between YHWH and the people in the land. ${ }^{29}$ 39:14; 40:6 and 42:10 attest to the solidarity Jeremiah demonstrated with those who remained in the land under Gedaliah's leadership. ${ }^{30} 40: 11$ depicts the people remaining in the land as a remnant (שארית). In 40:7-12 Gedaliah's community is portrayed to a large extent as a result of exile, but at the same time as bearing the potential to overcome exile. ${ }^{31}$

26 Contra Peter Diepold, Israel's Land (Stuttgart: Kohlhammer, 1972), 130.

27 Cf. Leslie C. Allen, Jeremiah: A Commentary (Louisville, Ken: Westminster John Knox, 2008), 367. Lundbom suggests that one may well imagine that Hanamel also put some of his 17 shekels of silver into an earthenware jar and hid it for safekeeping. Cf. Jack R. Lundbom, Jeremiah 21-36: A New Translation with Introduction and Commentary (Doubleday: New York, 2004) 510.

28 Cf. Mark Roncace, Jeremiah, Zedekiah and the Fall of Jerusalem (London: T \& T Clark, 2005), 123.

29 Cf. Thomas Römer, "Is there a Deuteronomistic Redaction in the Book of Jeremiah?," in Israel constructs its History: Deuteronomistic Historiography in Recent Research (ed. Albert De Pury, Thomas Römer and Jean-Daniel Macchi; Sheffield: Sheffield Academic Press, 2000), 412.

30 Cf. Seitz, Theology in Conflict, 219. Leuchter believes that Jer. 37-45, an integral part of chapters 26-45, was shaped by someone with strong ideological sympathies to the Judeans in exile in Babylon. Cf. Mark Leuchter, The Polemics of Exile in Jeremiah 26-45 (Cambridge: Cambridge University Press, 2008), 12. Leuchter does, however, concur that Jer. 26-45 had many sources, annalistic accounts and echoes of folk traditions. Cf. Polemics of Exile, 168-169. Although Jer. 26-45 may exhibit a sophisticated narrative structure, it is possible that material that originally supported the views of the people remaining in the land, was incorporated.

31 Cf. Ehud Ben Zvi, "The Voice and Role of a Counterfactual Memory in the Construction of Exile and Return: Considering Jeremiah 40:7-12," in The Concept of 
2 Kings 25:11-12 explicitly mentions that Nebuzaradan did not deport everyone in 587 B.C.E., but left the poorest people of the land (מדלת הארץ). Verse 12 reports that the Babylonian officer left vinedressers and ploughmen to מעל אדמתו מעו in 2 Kings 25:21 as well as the word כליגל יהודה in Jeremiah 43:4-5 should not be taken literally. It is hyperbolic language in order to express a great calamity. ${ }^{33}$ Archaeological evidence suggests that with the possible exception of Tell el-Fûl, Benjaminite sites escaped punishment at the hands of the Babylonians in 587 B.C.E. ${ }^{34}$

Ezekiel 33:24 suggests that the inhabitants of Judah, who had not been taken into exile, were claiming the land. Generally, this claim is linked to the people who remained in the land after 597 B.C.E. However, to call the population of the country ישבי החרבות האלה, "the inhabitants of these ruins" (Ezekiel 33:24), is scarcely feasible prior to 587 B.C.E. The list in verse 27 of the places (ruins, open country, strongholds and caves) where judgement would reach these survivors seems a traditional formulation rather than an actual reflection of the actual situation in the post-587 B.C.E. As John Kessler has remarked, it is likely that the oracle's content had been redactionally configured to suggest the inclusion also of the exiles who subsequently joined the 597 group. ${ }^{35}$ Evidently the people remaining in the land after 587 B.C.E. expected a continued existence in the land.

Jeremiah performed the act of purchasing the field of Hanamel in the presence of the required witnesses and the other people in the court of the guard (cf. Jer. 32:12). The transaction thus became not only a private transfer of property,

Exile in Ancient Israel and its Historical Concepts (ed. Ehud Ben Zvi and Christoph Levin; Berlin: De Gruyter, 2010), 178.

32 Cf. Hans H. Barstad, "After the 'Myth of the Empty Land': Major challenges in the Study of Neo-Babylonian Judah," in Judah and the Judeans in the Neo-Babylonian Period (ed. Oded Lipschitz and Joseph Blenkinsopp; Winona Lake, Ind.: Eisenbrauns, 2003), 12.

33 Bustenay Oded, "Where is the 'Myth of the Empty Land' to be found? History versus Myth," in Judah and the Judeans in the Neo-Babylonian Period (ed. Oded Lipschitz and Joseph Blenkinsopp; Winona Lake, Ind.: Eisenbrauns, 2003), 59.

34 Cf. Barstad, "Myth of the Empty Land," 6; Joseph Blenkinsopp, "Benjamin Traditions Read in the Early Persian Period," in Judah and the Judeans in the Persian Period (ed. Oded Lipschitz, and Manfred Oeming; Winona Lake, Ind.: Eisenbrauns, 2006), 466.

35 John Kessler, "Images of Exile: Representations of the 'Exile' and 'the Empty Land' in Sixth to Fourth Century BCE Yehudite Literature," in The Concept of Exile in Ancient Israel and its Historical Concepts (ed. Ehud Ben Zvi and Christoph Levin; Berlin: De Gruyter, 2010), 321. 
but also a communication event. ${ }^{36}$ The purchasing of land by the prophet, who previously announced that the land would be lost, would in all likelihood be of great significance, especially to those who remained in Judah after 587 B.C.E.

The emphasis in Jeremiah 32:6-15 on the continuing possession of the land, through both the law of the redeemer (משפט הגאלה) and the divine permission to possess the land (משפט הירשה), with no interruption that might symbolize exile, leads Rom-Shiloni to infer that the promise of possession in verse 15 has immediate significance; that is, it applies to those who remained in Judah. ${ }^{37}$ The adverb עד in 32:15 is indeed open to more than one reading. It may express a new beginning ("again") or continuality (in English translation: "continually"). ${ }^{38}$ The latter reading would have supported the interests of the remainees. Jeremiah's refusal of the offer of Nebuzaradan to accompany him to Babylon furthermore legitimated the idea that God was on the side of the people remaining in the land. ${ }^{39}$ It is reasonable that the people remaining in the land at least up till the murder of Gedaliah linked their hope for a continued existence in the land to Jeremiah's purchase of land in Anathoth. ${ }^{40}$

Römer attributes the absence of the prophet Jeremiah in the so-called Deuteronomistic History to the prophet's support of the views of those who were left in the land after 597/587 B.C.E. The redactors of the Deuteronomistic History were therefore not eager to mention Jeremiah at the end of their historiography. In the first Deuteronomistic edition of the book of Jeremiah the prophet is, however, depicted as a member of the Deuteronomistic party. ${ }^{41}$ The original account in Jeremiah 32:6b-15 of the prophet's purchase of the field of Hanamel is seemingly supported the views of the people remaining in the land.

36 Cf. Kelvin G. Friebel, Jeremiah's and Ezekiel's Sign-acts: Rhetorical nonverbal Communication (Sheffield: Sheffield Academic Press, 1999), 318.

37 Cf. Dalit Rom-Shiloni, Exclusive Inclusivity: Identity Conflicts between the Exiles and the People who Remained $\left(6^{\text {th }}-5^{\text {th }}\right.$ Centuries BCE) (New York: Bloomsbury T \&T Clark, 2015), 227.

38 Cf. Josef M. Oesch, "Zur makrostruktur und Textintentialität von Jer 32," in Jeremia und die "deuteronomistische Bewegung" (ed. Walter Gross; Weinheim: Beltz Athänaum, 1995), 216-217; Stegeman "Reading Jeremiah", 52.

39 Cf. Thomas C. Römer, "How did Jeremiah become a Convert to Deuteronomistic Ideology?" in Those Elusive Deuteronomists: The Phenomenon of Pan-Deuteronomism (ed. Linda S. Schearing and Steven L. McKenzie; Sheffield: Academic Press, 1999), 196. Cf. also Hardmeier, "Jeremia 32,2-15*", 207; Seitz, Theology in Conflict, 217. Leuchter does, however, believe that it is difficult to imagine that any remnant group in Judah would have chosen Jeremiah as a mouthpiece of its interests since the prophet had cast his allegiance with the community that settled in Babylon as early as 597 B.C.E. Cf. Leuchter, Polemics of Exile, 8.

40 According to Jer. 52:38 a third group of Judeans was deported in 582 B.C.E.

41 Römer, “A Convert to Deuteronomistic Ideology," 196-197. 
This perspective was, however, suppressed by redactors who promoted the interests of the Babylonian exiles, as will be seen in die following sections.

\section{The Perspective of a Goal-orientated Group}

Jeremiah 32:16-44 represents an extended interpretation of the sign-act in verses 6-15. Although the lawsuit speech by YHWH (verses 26-35) seemingly stands in heavy tension with the prophet's prayer (verses 16-25), they are linked by the common use of the verb פלא in verse 17 as well as 27. 32:26-35 is positioned to be a response to $32: 16-25 .^{42}$

Despite the fact that Jeremiah 32:36-41 seemingly responds to the preceding doom oracle, it stands contextually in complete isolation. ${ }^{43}$ While 32:26-35 refers to the Judeans in the third person, the second-person address appears in $32: 36 .{ }^{44}$ It is therefore no surprise that $32: 36-41$ has frequently been regarded as a later addition. ${ }^{45}$

Jeremiah 32:42-44, which is introduced by the כה אמר יהוה-formula, forms a fitting contrast to the devastation announced in 32:28-35. The description of the attack by the Babylonians with the phrase את כל־הרעה in verses 23 and 42 signifies the link between 32:16-25 and 32:42-44. In addition, the reference to the "field" in verse 43 refers back to verse $25 .{ }^{46}$ Verse 44 expounds the promise in verse 15. It does, however, extend the land in which fields again will be bought from Anathoth to the areas around Jerusalem, the towns in Judah, the hill country and the Negev. In addition, it promises the restoration of fortunes.

In his prayer, Jeremiah 32:16-25, the prophet highlights the incongruity of the message of the sign-act with contemporary circumstances. ${ }^{47}$ It was obvious that Jerusalem had come to its final ending in sword, famine and pestilence (verses 23b-24). ${ }^{48}$ In 32:28-29 YHWH confirms that he was indeed giving Jerusalem into the hands of the Babylonians. 32:42-44 does, however, recount what YHWH, for whom nothing was impossible (verse 27), would do in the

\footnotetext{
42 Cf. Brueggemann, “A 'Characteristic Reflection',” 24.

43 Cf. Dalit Rom-Shiloni, "The Prophecy for 'Everlasting Covenant' (Jeremiah XXXII:36-41): an Exilic Edition of a Deuteronomistic Redaction,”VT 53 (2003): 207. 44 Singular in the LXX and plural in the Masoretic text.

45 Cf. for instance Siegmund Böhmer, Heimkehr und neuer Bund: Studien zu Jeremiah 30-31 (Göttingen: Vandenhoeck \& Ruprecht, 1976:43); Johan Lust, “'Gathering and Return' in Jeremiah and Ezekiel." In Le Livre de Jérémie: Le Prophète et son Milieu. Les Oracles et leur Transmission (ed. Pierre-Maurice Bogaert. Leuven: Uitgeverij Peeters, 1981), 136.

46 Cf. Brueggemann, “A 'Characteristic Reflection',” 28.

47 Cf. Friebel, Jeremiah's and Ezekiel's Sign-acts, 315.

48 Cf. Brueggemann, "A 'Characteristic Reflection'," 22.
} 
future. Fields would again be bought in the land of Benjamin, in the areas around Jerusalem, in the cities of Judah, the hill country and the Negev.

Hopes originally associated with Jeremiah's purchase of a field in Anathoth, at a point prior to the fall of Jerusalem, now relate purely to the return and re-occupation of the land. ${ }^{49}$ The references to the people of Israel and Judah in Jeremiah 32:30, 32, are indicative of the fact that 32:26-35, 42-44 were written from the perspective of the Babylonian exiles. ${ }^{50}$ This is confirmed by the quotation in verse 43: "this land of which you ${ }^{51}$ are saying: 'It is desolate, without human being or animal. It has been given into the hands of the Chaldeans.",

Deuteronomistic terminology and subject matter are particularly noticeable in Jeremiah 32: 30-35, 42-44. 32:16, 17*, 24-25 probably display earlier material. In its current form verses $16-25$ seemingly belong to the same redaction that is encountered in verses $25-35,42-44$.

Jeremiah 32:16-35, 42-44 presents an interpretation of Jeremiah's signact. ${ }^{52}$ These verses were evidently written from the perspective of the Babylonian exiles. To these exiles, who regarded the land as desolate and without human or animal, hope for a future restoration is provided. The significance of the purchase of the field in Anathoth has shifted entirely to the future. From this perspective the adverb עד in 32:15 expresses a new beginning ("again"). The voice of the people remaining in the land has been silenced.

\section{The Perspective of a Second Goal-orientated Group}

As was noted earlier, Jeremiah 32:36-41 has frequently been regarded as a later addition. Despite the fact that the fulfilment of YHWH's message of judgement is made the guarantee of the fulfilment of his message of salvation in $32: 36,{ }^{53}$

\footnotetext{
49 Seitz, Theology in Conflict, 245.
}

50 Sharp traces it to a pro-golah group that closed off the possibility of all other Israelites other than those in the Babylonian diaspora. Cf. Sharp, Prophecy and Ideology, 158-159.

51 The MT reads second person plural in contrast to the LXX second person singular reading. The plural in the MT represents a generalization for the exilic community. Cf. William L. Holladay, A Commentary on the Book of Jeremiah: Chapters 26-52 (Minneapolis: Fortress Press, 1989), 207.

52 Cf. Mastnjak, Deuteronomy, 158. He views the whole of Jer. 32:16-44 as a Deuteronomistic composition.

53 Cf. John Applegate, "'Peace, Peace, when there is no Peace.' Redactional Integration of Prophecy of Peace into the Judgement of Jeremiah," in The Book of Jeremiah and its Reception (ed. Adrian H.W. Curtis and Thomas Römer; Leuven: Leuven UP, 1997), 82. 
the introductory ועתה marks a decisive discontinuity from the preceding verses. ${ }^{54}$ Rom-Shiloni has noted that in thematic and lexical details 32:36-41 are close to prophecies of Ezekiel and Deutero-Isaiah. In addition, the theme of an everlasting covenant between YHWH and his people is introduced: a theme not otherwise dealt in chapter $32 .{ }^{55}$ Rom-Shiloni has also noted that no less than ten hapax legomena in terms of the rest of the book of Jeremiah occur in these verses. ${ }^{56}$ The author of 32:36-41 evidently addresses the people in the diaspora ("I will collect them from all the countries"), ${ }^{57}$ who will be gathered and brought back (verse 37 ). It seems to be an alternative promise to the exiles. ${ }^{58}$

Stegeman suggests that exile and return gain a more symbolic meaning in Jeremiah 32:36-41. One may live in the land, but still be in exile, in a situation of religious shortcoming. What lies behind the insertion of 32:36-41 in the text is no longer a group pressing for return and ownership of the land, but apparently a group pressing for religious renewal, a group that has Jerusalem as its centre, while also including the Diaspora. ${ }^{59} 32: 36-41$ would thus reflect a different view of the land than that which is encountered elsewhere in the chapter. The insertion of verses 36-41 has clearly changed the perspective of chapter 32 as a whole. ${ }^{60}$ YHWH's eternal covenant with Israel takes centre stage. The return from exile, announced in verse 37, is nonetheless of great importance. YHWH will plant them in the land (verse 41). Covenant and land-related blessing are obviously two sides of the same coin. ${ }^{61}$

Jeremiah 32:36-41 offers the perspective of a second goal-orientated group. Through the insertion of these verses, the final form of chapter 32 was transformed. Although the notion of the empty land is not explicitly mentioned, the author of 32:36-41, who had the last word, takes it for granted.

\section{THE NOTION OF THE EMPTY LAND}

As was noted earlier, archaeological evidence suggests that with the possible exception of Tell el-Fûl, Benjaminite sites escaped punishment at the hands of the Babylonians in 587 B.C.E. The Benjaminite area even seemed to have prospered during most of the sixth century before entering into a period of

\footnotetext{
54 Brueggemann, "A 'Characteristic Reflection'," 26-27. עתה fulfils an adverbial function. It expresses the contrast between the YHWH's acts of judgment and his future acts of restoration.

55 Cf. Rom-Shiloni, "Everlasting Covenant," 221.

56 Cf. Rom-Shiloni, "Everlasting Covenant," 211.

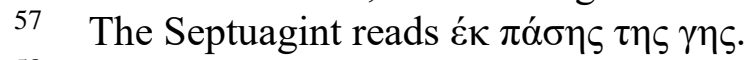

58 Cf. Rom-Shiloni, "Everlasting Covenant," 208.

59 Stegeman, "Reading Jeremiah," 46.

60 Cf. Stegeman "Reading Jeremiah," 45.

61 Allen, Jeremiah, 371.
} 
decline at the beginning of the Persian Epoch. ${ }^{62}$ However, as far as Judah is concerned, archaeological finds do provide a picture not of a flourishing civilization, but rather of a self-sustaining rural society. ${ }^{63}$ Despite the fact that Judah proper was destroyed and the Judeans must have experienced losses in human life of a ghastly magnitude, ${ }^{64}$ the land was nonetheless far from empty as is implied by Jeremiah 32:43. The fact that the author remarks that his addressees were describing the land as desolate, devoid of humans and animals (אדם ובהמה), אתם אמרים שממה היא מאין , את , suggests that he was corresponding directly to the concerns of his contemporaries. ${ }^{65}$

It has been asserted that the notion of the empty land was an ideological tool invented by the returnees to bolster their claims of landownership and political power against those who had stayed behind in Judah. ${ }^{66}$ Since the Babylonians deported the upper classes of the Judean population to Babylonia, it is tempting to view them as an exploitative elite. As was noted earlier, Nebuzaradan gave the poor people "vineyards and fields".

The presence of the notion of the empty land was not necessarily linked to claims of landownership. In Chronicles and the Holiness Code the exile is regarded as compensation for the Sabbaths of which the land had been deprived for so long. ${ }^{67}$ Rom-Shiloni does, however, trace the concept of the empty land back to the prophet Ezekiel, who in his prophecies of consolation envisioned the return of the exiles to an empty land. ${ }^{68}$ Most of the Babylonian exiles did not return when circumstances made a return possible. Consequently, Becking speaks about the myth of mass return. He argues that the idea of a "mass return"

62 Cf. Hermann-Josef Stipp, "The Concept of the Empty Land in Jeremiah 37-43," in The Concept of Exile in Ancient Israel and its Historical Concepts (ed. Ehud Ben Zvi and Christoph Levin; Berlin: De Gruyter, 2010), 142.

63 Cf. Kirsi Valkama, "What do Archaeological Remains reveal of the Settlements in Judah during the Mid-Sixth Century," in The Concept of Exile in Ancient Israel and its Historical Concepts (ed. Ehud Ben Zvi and Christoph Levin; Berlin: De Gruyter, 2010), 58.

64 Cf. Stipp, “Jeremiah 37-43,” 149.

65 Cf. Allen, Jeremiah, 371.

66 Cf. Stipp, “Jeremiah 37-43," 105.

67 Cf. Stipp, "Jeremiah 37-43," 115. Stipp finds signs of the concept of the empty land in the narrative forming the basis of what is now Jer. 37-43, which he labels: "The Narrative of Judah's downfall in Palestine." Stipp believes that this narrative was written in Babylon by an author who tried to win over his fellow exiles for a more conciliatory stance in relation to their Babylonian overlords. Cf. Stipp, "Jeremiah 37$43, " 154$.

68 Cf. Rom-Shiloni, Exclusive Inclusivity, 258; idem, "What is 'Persian' in Late Six Century B.C.E. Prophetic Literature? Case Studies and Criteria," in On Dating Biblical Texts to the Persian Period: Discerning Criteria and Establishing Epochs (ed. Richard J. Bautch and Mark Lackowski; Tübingen: Mohr Siebeck, 2019), 36. 
should be regarded as a social construct that served the interests of a specific group around 400 B.C.E. ${ }^{69}$

Ben Zvi has asserted that the social success of the concept of the "total exile" and the "empty land" cannot be explained in terms of their supposed function in an exclusivist, discriminatory and oppressive social system imposed by a community of exiles / returnees over and against a community of remainees that included the vast majority of Yehud. Ben Zvi believes that the adaptation of the idea of "total exile" was seemingly done by Benjaminites and other remainees for the sake of social cohesion and the construction of self-identity in Persian Yehud. ${ }^{70}$ Ben Zvi's argument is debatable since Ezra-Nehemiah regards all inhabitants of the land which were not repatriated as "foreigners."71

It is noteworthy that the emphasis in Jeremiah 32:36-41 is not on the land as such, but on the establishment of an eternal covenant. ${ }^{72}$ YHWH's commitment to the new relationship with his people would result in him planting them in the land (cf. 32:41). Future life in the land would nevertheless be a sign of divine favour. In addition, the notion of the empty land is taken for granted.

\section{THE LAND IN JEREMIAH 32}

Jeremiah 32 does not merely link the collection of salvation oracles in chapters 30-31 to the Jeremiah narratives, ${ }^{73}$ but the prophet's purchase of a field in Anathoth from his nephew Hanamel was a metonymic expression for the resumption of normal economic, societal, familial and covenantal activities in the land. ${ }^{74}$ Jeremiah 32 thus underscores the importance of the land for Israel.

69 Bob Becking, "'We all Returned as One!' Critical Notes on the Myth of Mass Return," in Judah and the Judeans in the Persian Period (ed. Oded Lipschitz and Manfred Oeming; Winona Lake, Ind.: Eisenbrauns, 2006), 12-13.

70 Ehud Ben Zvi, "Total Exile, Empty Land and the General Intellectual Discourse in Yehud," in The Concept of Exile in Ancient Israel and its Historical Concepts (ed. Ehud Ben Zvi and Christoph Levin; Berlin: De Gruyter, 2010), 167.

71 Cf. Rom-Shiloni, Exclusive Inclusivity, 261. The עם הארץ, who are viewed as the enemies of Judah in Ezra 4, were possibly the descendants of those who remained in the land after 587 B.C.E. Cf. Johannes U. Ro, Poverty, Law and Divine Justice in Persian and Hellenistic Judah (Atlanta: SBL Press, 2018), 68.

72 Römer has suggested that the Deuteronomistic formula "the land given to the ancestors" is transformed in Jer. 44:10 to that of the "Torah given to the ancestors." The latter formula could express the interest of a Golah in the diaspora for whom the Torah becomes the means par excellence to speak of the relation between YHWH and Israel. Cf. Römer, "A Deuteronomistic Redaction," 419.

73 Cf. Albertz, Israel in Exile, 317.

74 Cf. Friebel, Jeremiah's and Ezekiel's Sign-acts, 321 
Jeremiah 32:2275 explicitly states that YHWH had given (the verb נתן) the land to the people. Possession of the land meant the fulfilment of YHWH's promises to their ancestors. ${ }^{76}$ Israel merely took possession of the land, ${ }^{77}$ a land of milk and honey. The possession and habitation of the land could, however, not be considered permanent, uninterrupted privileges. ${ }^{78}$ The people would lose the land despite the promises to the fathers. Because the people did not act in accordance with YHWH's commands, the Babylonians were fighting against Jerusalem.

Future life in the land, whether it meant a continued existence in the land following the events in 587 B.C.E., or a return from exile, was totally dependent on Yahweh's action. Jeremiah 32:41 explicitly states that YHWH would plant (yט) the exiles in the land. It would be entirely the result of YHWH's mercy. Remarkably the promise of the land to the ancestors does not play a role in the hope of a future life in the land. The fall of Jerusalem and the resulting exile discredited any argument that the patriarchal promise of the land meant that God was obligated to deliver the land from foreign incursions.

Exile stood for a partial estrangement between YHWH and Israel. ${ }^{79}$ To be in the land denoted that you were the "true Israel". This implied that those who remained in the land under Gedaliah's leadership after 587 B.C.E. could argue that God was on their side. The Babylonian exiles, however, applied the promise with life in the land associated with Jeremiah's purchase of the field in Anathoth to themselves. The significance of the purchase of the field in Anathoth was thus shifted entirely to the future.

Most of the Babylonian exiles did not return when circumstances made a return possible. As is revealed by the insertion of Jeremiah 32:36-41, the distinct link between Israel and the land nonetheless persisted. ${ }^{80}$ Mafico notes that the

75 Jer 32:21-22 is composed entirely of phrases drawn from the first-fruits liturgy in Deut. 26:3-11. The only phrase in Jer. 32:21 not paralleled in Deut. 26:8 is “your people, Israel." This phrase, however, appears verbatim in near proximity in Deut. 26:15. An impressive congruency of six phrases occurs in an almost identical order. Cf. Mastnjak, Deuteronomy, 157-158.

76 In Jer. $7: 7 ; 16: 15 ; 24: 10 ; 25: 5 ; 30: 3$ and $35: 15$ the term "fathers" refers to the generation which experienced the exodus. No clear distinction is made in 11:5 between the patriarchs and the generation which experienced the exodus (compare verses 4 and 5). 32:22, however, contains a clear reference to the patriarchs.

77 Cf. the verb ירש in verse 23.

78 Cf. Friebel, Jeremiah's and Ezekiel's Sign-acts, 324.

79 Cf. Ben Zvi, "Counterfactual Memory," 173.

80 Davies suggests that the belief in the "umbilical" nature of the relationship of Israel to the land contributed to the tensions that prevailed in the early decade of first-century B.C.E. Palestine. Cf. William D. Davies, The Gospel and the Land: Early Christianity and Jewish Territorial Doctrine (Sheffield: JSOT Press, 1994), 157. 
land defined who a person was among the Africans and the Israelites. ${ }^{81}$ This observation should evidently be taken into consideration when contemporary land issues are considered.

\section{E IMPLICATIONS FOR THE DISCUSSION OF CONTEMPORARY LAND ISSUES}

The New Testament redefines land. Whereas "land" in the Old Testament refers to Israel's life in Canaan, in the New Testament "land" is transmuted to refer to life in Christ. ${ }^{82}$ Burge aptly asserts that ownership of the land was not a Christian question. ${ }^{83}$ Christians nonetheless live in a world in which questions of land ownership are frequently encountered. By refusing to face land issues, Christianity may have served to sanction existing inequalities. ${ }^{84}$

One should take the gap between the world of sixth century Judah and our contemporary world into account when considering contemporary land issues. It has been observed that traditions of land ownership in ancient Israel and in Africa have as their foundation the basic idea that God is the primary owner of the land. ${ }^{85}$ Jeremiah 32 clearly proceeds from the assumption that the land belonged to YHWH. However, for the people who remained in Judah after 587 B.C.E. as well as those taken into exile the land was a measuring gauge of the relationship between them and YHWH. ${ }^{86}$ The same cannot necessarily be said about conception of the land in Africa.

Habel has rightly remarked that it is no longer possible to cite the position of the Bible on land as if that position is singular and obvious. ${ }^{87}$ As this analysis of Jeremiah 32 has demonstrated, even a single chapter in the Old Testament may reveal conflicting views on the land. Successive redactions have silenced the voice of the people who remained in the land after 587 B.C.E. As Mosala and West have advocated, the ideologies that are underlying the different redactional stages of a text should be determined.

Christians should strive for social justice with regard to the land. The use of the concept of the "empty land" by the Babylonian exiles to deny the people

81 Cf. Temba L.J. Mafico, "Land Concept and Tenure in Israel and African Tradition," in Postcolonial Perspectives in African Biblical Interpretations (ed. Musa W. Dube, Andrew M. Mbuvi and Dora Mbuwayesango; Atlanta: Society of Biblical Literature, 2012), 238.

82 Cf. Bruce K. Waltke, An Old Testament Theology: An Exegetical, Canonical, and Thematic Approach (Grand Rapids, MI.: Zondervan, 2007), 560.

83 Gary M. Burge, Jesus and the Land: The New Testament Challenge to "Holy Land" Theology (Grand Rapids, MI.: Baker Academic, 2010), 127.

84 Cf. for instance the accusation by Brueggemann, The Land, 193.

85 Mafico, "Land concept," 235.

86 To use Wright's formulation. Cf. Wright, Old Testament Ethics, 96.

87 Habel, The Land, xii. 
who remained in the land any claim to the land cautions against the effect ideologies may have when contemporary land issues are addressed. Despite the fact that those who remained in the land after 587 B.C.E. also worshipped YHWH, the Babylonian exiles did not regard themselves as belonging to the people of YHWH. The ideology of apartheid presents us with a modern parallel.

\section{F CONCLUSION}

This study has shown some of the pitfalls one faces when attempting to use the Old Testament in the present-day debate on land. Jeremiah 32 is a multi-layered text presenting evidence of the adaptation of Jeremiah's sign-act by various groups. It is likely that the oldest core of the chapter, verses $6 b-15$, presents the perspective of the people remaining in Judah after 587 B.C.E. An editor, who expressed the perspective of the Babylonian exiles, appended verses $6 \mathrm{~b}-15$. The significance of the purchase of the field in Anathoth was shifted entirely to the future. The people will be restored to the land, which now is regarded as desolate and without human or animal. The Babylonian exiles are the true Israel. In its final form Jeremiah 32 offers the perspective of another gola-orientated editor. Although the land remains important, YHWH's eternal covenant with Israel takes centre stage. The voice of the people who remained in the land after 587 B.C.E. remains silenced.

Although the uncovering of conflicting perceptions with regard to the land demonstrates that the use of Jeremiah 32 in present-day reflections on the land question is risky, the chapter highlights the importance of land issues. Biblical texts relating to land issues should be subjected to an exhaustive redactional analysis, in order to determine the ideologies underlying the different redactional stages of the texts. The use of the concept of the "empty land" by the Babylonian exiles to deny the people who remained in the land any claim to the land cautions against the role which ideologies may play in contemporary land issues.

\section{BIBLIOGRAPHY}

Albertz, Rainer. Israel in Exile: The History and Literature of the Six Century B.C.E. Translated by David Green. Atlanta: Society of Biblical Literature, 2003.

Allen, Leslie C. Jeremiah: A Commentary. OTL. Louisville, Ken.: Westminster John Knox, 2008.

Applegate, John. "'Peace, Peace, when there is no Peace.' Redactional Integration of Prophecy of Peace into the Judgement of Jeremiah." Pages 51-89 in The Book of Jeremiah and its Reception. Edited by Adrian H.W. Curtis and Thomas Römer. BETL 128. Leuven: Leuven UP, 1997.

Barstad, Hans H. "After the 'Myth of the Empty Land': Major challenges in the Study of Neo-Babylonian Judah." Pages 3-20 in Judah and the Judeans in the Neo- 
122 Terblanche, "Future Belongs to us," OTE 33/1 (2020): 107-124

Babylonian Period. Edited by Oded Lipschitz and Joseph Blenkinsopp. Winona Lake, Ind.: Eisenbrauns, 2003.

Becking, Bob. "'We all returned as One!' Critical Notes on the Myth of Mass Return," Pages 3-18 in Judah and the Judeans in the Persian Period. Edited by Oded Lipschit and Manfred Oeming. Winona Lake, Ind.: Eisenbrauns, 2006

Ben Zvi, Ehud."Total Exile, Empty Land and the General Intellectual Discourse." Pages 155-168 in The Concept of Exile in Ancient Israel and its Historical Concepts. Edited by Ehud Ben Zvi and Christoph Levin. BZAW 404. Berlin: De Gruyter, 2010. https://doi.org/10.1515/9783110221787.155.

Ben Zvi, Ehud. "The Voice and Role of a Counterfactual Memory in the Construction of Exile and Return: Considering Jeremiah 40:7-12." Pages 169-188 in The Concept of Exile in Ancient Israel and its historical Concepts. Edited by Ehud Ben Zvi and Christoph Levin. BZAW 404. Berlin: De Gruyter, 2010. https://doi .org/10.1515/9783110221787.169.

Blenkinsopp, Joseph. "Benjamin Traditions Read in the Early Persian Period." Pages 629-645 in Judah and the Judeans in the Persian Period. Edited by Oded Lipschitz and Manfred Oeming. Winona Lake, Ind.: Eisenbrauns, 2006.

Böhmer, Siegmund. Heimkehr und neuer Bund: Studien zu Jeremia 30-31. GTA 5. Göttingen: Vandenhoeck \& Ruprecht, 1976.

Brueggemann, Walter. The Land. Overtures to Biblical Theology. London: SPCK, 1978.

Brueggemann, Walter. 1996. "A 'characteristic' reflection on what comes next (Jeremiah 32.16-44)." Pages 16-32 in Prophets and Paradigms: Essays in Honour of Gene M. Tucker. Edited by Stephen B. Reid. JSOTS 229. Sheffield: Sheffield Academic Press.

Burge, Gary M. Jesus and the Land: The New Testament Challenge to "Holy Land" Theology. Grand Rapids, MI: Baker Academic, 2010.

Carroll, Robert P. Jeremiah: A Commentary. OTL. London: SCM Press, 1986.

Davies, William D. The Gospel and the Land: Early Christianity and Jewish Territorial Doctrine. Sheffield: JSOT Press, 1994

Diepold, Peter. Israel's Land. BWANT 95. Stuttgart: Kohlhammer, 1972.

Friebel, Kelvin G. Jeremiah's and Ezekiel's Sign-acts: Rhetorical nonverbal Communication. JSOTSS 283. Sheffield: Sheffield Academic Press, 1999.

Habel, Norman C. The land is mine: Six Biblical Land Ideologies. Overtures to Biblical Theology. Minneapolis: Fortress, 1995.

Hardmeier, Christof. "Jeremiah 32,2-15* als Eröffnung der Erzählung von der Gefangeneschaft und Befreiung Jeremias in Jer 34,7; 37,3-40,6*." Pages 187-214 in Jeremiah und die "deuteronomistische Bewegung". Edited by Walter Gross. Weinheim: Beltz Athänaum, 1995.

Holladay, William L. A Commentary on the Book of Jeremiah: Chapters 26-52. Hermeneia. Minneapolis: Fortress Press, 1989.

Kessler, John. "Images of Exile: Representations of the 'Exile' and 'the Empty Land' in Sixth to Fourth Century BCE Yehudite Literature." Pages 309-351 in The Concept of Exile in Ancient Israel and its Historical Concepts. Edited by Ehud Ben Zvi and Christoph Levin. BZAW 404. Berlin: De Gruyter, 2010.

Leuchter, Mark. The Polemics of Exile in Jeremiah 26-45. Cambridge: Cambridge University Press, 2008. https://doi.org/10.1017/CBO9780511551147. 
Lundbom, Jack R. Jeremiah 21-36: A New Translation with Introduction and Commentary. Anchor Bible 21B. Doubleday: New York, 2004.

Lust, Johan. "'Gathering and Return' in Jeremiah and Ezekiel." Pages 119-142, in Le Livre de Jérémie: Le Prophéte et son Milieu. Les Oracles et leur Transmission. Edited by Pierre-Maurice Bogaert. BETL 54. Leuven: Uitgeverij Peeters, 1981.

McKane, William. A Critical and Exegetical Commentary on Jeremiah: Volume II. ICC. London: Bloomsbury, 2014.

Mafico, Temba L.J. "Land Concept and Tenure in Israel and African Tradition." Pages 235-244 in Postcolonial Perspectives in African Biblical Interpretations. Edited by Musa W. Dube, Andrew M. Mbuvi and Dora Mbuwayesango. Global Perspectives on Biblical Scholarship 13. Atlanta: Society of Biblical Literature, 2012.

Mastnjak, Nathan. Deuteronomy and the Emergence of Textual Authority in Jeremiah. FAT 2/87. Tübingen: Mohr Siebeck, 2016. https://doi.org/10.1628/978-3-16-154 $\underline{402-6 .}$.

Mosala, Itumeleng J. Biblical Hermeneutics and Black Theology in South Africa. Grand Rapids: Eerdmans, 1990.

Oded, Bustenay. "Where is the 'Myth of the Empty Land' to be found? History versus Myth." Pages 55-74 in Judah and the Judeans in the Neo-Babylonian Period. Edited by Oded Lipschitz and Joseph Blenkinsopp. Winona Lake, Ind.: Eisenbrauns, 2003.

Oesch, Josef M. "Zur makrostruktur und Textintentialität von Jer 32,” Pages 215-223 in Jeremiah und die "deuteronomistische Bewegung”. Edited by Walter Gross. Weinheim: Beltz Athänaum, 1995.

Pohlmann, Karl-Friedrich. Studien zum Jeremiabuch: Ein Beitrag zur Frage nach der Entstehung des Jeremiabuches. FRLANT 118. Göttingen: Vandenhoeck \& Ruprecht, 1978. https://doi.org/10.13109/9783666532771.

Ro, Johannes U. Poverty, Law and Divine Justice in Persian and Hellenistic Judah. Atlanta: SBL Press, 2018. https://doi.org/10.2307/j.ctt22h6pxw.

Römer, Thomas C. "Is there a Deuteronomistic Redaction in the Book of Jeremiah?" Pages 399-421 in Israel constructs its History: Deuteronomistic Historiography in Recent Research. Edited by Albert De Pury, Thomas Römer and Jean-Daniel Macchi. JSOTSS 306. Sheffield: Sheffield Academic Press, 2000.

Römer, Thomas C. "How did Jeremiah become a Convert to Deuteronomistic Ideology?" Pages 189-199 in Those Elusive Deuteronomists: The Phenomenon of Pan-Deuteronomism. Edited by Linda S. Schearing and Steven L. McKenzie. JSOTSS 268. Sheffield: Academic Press, 1999.

Rom-Shiloni, Dalit. "The Prophecy for 'Everlasting Covenant' (Jeremiah XXXII:3641): an Exilic Edition of a Deuteronomistic Redaction.” VT 53 (2003): 201-223. https://doi.org/10.1163/156853303764664625.

Rom-Shiloni, Dalit. Exclusive Inclusivity: Identity Conflicts between the Exiles and the People who Remained ( $6^{\text {th }}-5^{\text {th }}$ Centuries BCE). LHB/ OTS 543; New York: Bloomsbury T \& T Clark, 2015.

Rom-Shiloni, Dalit. "What is 'Persian' in Late Six Century B.C.E. Prophetic Literature? Case Studies and Criteria," Pages 31-53 in On Dating Biblical Texts to the Persian Period: Discerning Criteria and Establishing Epochs. Edited by Richard J. Bautch and Mark Lackowski; FAT 2/101. Tübingen: Mohr Siebeck, 2019. 
124 Terblanche, "Future Belongs to us," OTE 33/1 (2020): 107-124

Roncace, Mark. Jeremiah, Zedekiah and the Fall of Jerusalem. JSOTSS 423. London: T \& T Clark, 2005.

Seitz, Christopher R. Theology in Conflict: Reactions to the Exile in the Book of Jeremiah. BZAW 176. Berlin: Walter de Gruyter, 1989. https://doi.org/10.1515 19783110866889.

Sharp, Carolyn J. Prophecy and Ideology in Jeremiah: Struggles for Authority in Deutero-Jeremainic Prose. London: T \& T Clark, 2003.

Stegeman, Janneke. "'Reading Jeremiah makes me angry!' The Role of Jeremiah 32[39]:36-41 in Transformation within the 'Jeremianic' Tradition." Pages 44-65 in Tradition and Innovation in Biblical Interpretation: Studies presented to Professor Eep Talstra on the Occasion of his Sixty-Fifth Birthday. Edited by Wido Th. van Peursen and Janet W. van Dyk, Leiden: Brill, 2011. https://doi. org/10.1163/9789004215184_005.

Stipp, Hermann-Josef. "The Concept of the Empty Land in Jeremiah 37-43." Pages 103-154 in The Concept of Exile in Ancient Israel and its Historical Concepts. Edited by Ehud Ben Zvi and Christoph Levin. BZAW 404. Berlin: De Gruyter, 2010.

Stulman, Louis. Order amid Chaos: Jeremiah as Symbolic Tapestry. The Biblical Seminar 57. Sheffield: Sheffield Academic Press, 1998.

Thiel, Windfried. Die deuteronomistiche Redaktion von Jeremia 26 bis 45: Mit einer Gesamtbeurteilung der deuteronomistichen Redaktion des Buches Jeremia. WMANT 52. Neukirchen-Vluyn: Neukirchener Verlag, 1981.

Valkama, Kirsi. "What do Archaeological Remains reveal of the Settlements in Judah during the Mid-Sixth Century." Pages 38-59 in The Concept of Exile in Ancient Israel and its Historical Concepts. Edited by Ehud Ben Zvi and Christoph Levin. BZAW 404. Berlin: De Gruyter, 2010.

Wafawanaka, Robert. "'The Land is Mine!' Biblical and Postcolonial Reflections on Land with particular Reference to the Land Issue in Zimbabwe." Pages 221-234 in Postcolonial Perspectives in African Biblical Interpretations. Edited by Musa W. Dube, Andrew M. Mbuvi and Dora Mbuwayesango. Global Perspectives on Biblical Scholarship 13. Atlanta: Society of Biblical Literature, 2012.

Waltke, Bruce K. An Old Testament Theology: An Exegetical, Canonical, and Thematic Approach. Grand Rapids, MI: Zondervan, 2007.

West, Gerald. "Redaction criticism as a Resource for the Bible as 'A Site of Struggle'." OTE 30 (2017): 525-545. https://doi.org/10.17159/2312-3621/2017/v30n2a19.

Wright, Christopher J.H. Old Testament Ethics for the People of God. Downers Grove: IVP Academic, 2004.

Zimmerli, Walter. "Das 'Land' bei den vorexilischen und frühexilischen Schriftpropheten." Pages 33-45 in Das Land Israel in biblischer Zeit: JerusalemSymposium 1981. Edited by Georg Strecker. GTA 25. Göttingen: Vandenhoeck \& Ruprecht, 1983.

Dr Marius Daniel Terblanche is a research fellow at the Department of Old and New Testament Studies, University of the Free State, Bloemfontein. Email: mdterblanche@absamail.co.za. ORCID: https://orcid.org/0000-0002-3141-8333. 